\title{
Testicular Atrophy
}

National Cancer Institute

\section{Source}

National Cancer Institute. Testicular Atrophy. NCI Thesaurus. Code C123259.

Loss of testicular volume. 